\title{
Pengaruh Kepemilikan Institusional, Kepemilikan Manajerial, Ukuran Perusahaan dan Leverage terhadap Integritas Laporan Keuangan
}

\author{
Widya Kusuma Wardhani ${ }^{1}$, Yuli Chomsatu Samrotun ${ }^{2}$ \\ Program Studi Akuntansi, Fakultas Ekonomi, Universitas Islam Batik Surakarta \\ Correspondence email: widyakusumawardhani31@gmail.com; chom_satoe@yahoo.com
}

\begin{abstract}
The study aims to determine the effect of institutional ownership, managerial ownership, company size and leverage on the integrity of financial statements. Dependent variable in this study are integrity of financial statements while the independent variables used in this study are institutional ownership, managerial ownership, company size and leverage. This research is focused on mining companies on the Indonesia Stock Exchange (IDX) period 2013-2018. The selection of samples in this study used the purposive sampling method, this obtained a sample of 54 sample data from the mining companies population listed on the Indonesia Stock Exchange (IDX) period 2013-2018. The analytical tools used in this study are multiple linear regression analysis. The results of this research show that the variable institutional ownership affect the integrity of financial statements, while the managerial ownership variables, company size and leverage do not affect the integrity of financial statements.
\end{abstract}

Keywords: Institutional Ownership; Managerial Ownership; Company Size; Leverage; Integrity of Financial Statements.

\section{PENDAHULUAN}

Laporan keuangan adalah informasi pada suatu perusahaan selama satu periode akuntansi yang dapat digunakan untuk menggambarkan kinerja suatu perusahaan (Kasmir, 2014). Integritas menurut (Mulyadi, 2011) adalah prinsip moral yang tidak memihak, jujur, seseorang yang berintegritas tinggi memandang fakta seperti apa adanya dan mengemukakan fakta tersebut seperti apa adanya. Apabila seorang auditor mengaudit laporan keuangan yang tidak berintegritas, maka peluang seorang auditor dituntut akan semakin besar. Karena laporan keuangan yang tidak berintegritas akan merugikan bagi pengguna laporan keuangan tersebut.

Kepemilikan institusional merupakan kondisi dimana institusi memiliki saham dalam suatu perusahaan. Kepemilikan institusional memiliki kemampuan untuk mengendalikan pihak manajemen melalui proses monitoring secara efektif sehingga dapat meningkatkan kinerja perusahaan. Kepemilikan institusional memiliki kemampuan untuk mengurangi insentif para manajer yang mementingkan diri sendiri melalui tingkat pengawasan yang insentif. Sehingga kepemilikan institusional diharapkan dapat menekan kecenderungan pihak manajemen dalam melakukan manipulasi laporan keuangan.

Ukuran perusahaan diduga menjadi salah satu faktor yang dapat mempengaruhi integritas laporan keuangan. Perusahaan-perusahaan skala besar akan dihadapkan dengan situasi di mana tuntutan terhadap perusahaan akan semakin besar dari para pemangku kepentingan dalam menyajikan informasi dalam laporan keuangan sesuai dengan keadaan keuangan yang sebenarnya dibandingkan dengan perusahaan berukuran kecil.

Penggunaan utang yang terlalu tinggi dalam aset perusahaan diduga dapat mempengaruhi manajemen untuk menyajikan informasi dalam laporan keuangan yang memiliki integritas atau tidak. Perusahaan yang memiliki leverage yang tinggi diduga menjadi lebih luas dalam menyajikan informasi dalam laporan keuangan sebagai upaya memikat investor dibandingkan dengan perusahaan yang memiliki tingkat rendah leverage. Perusahaan-perusahaan yang memiliki tingkat leverage yang tinggi tidak menutup kemungkinan bahwa perusahaan akan melakukan kecurangan dalam laporan keuangannya.

Fenomena perusahaan melakukan kecurangan penyajian laporan keuangan yang tidak berintegritas sekarang ini masih terjadi di Indonesia. Kecurangan dalam penyajian laporan keuangan dilakukan oleh BUMN seperti PT. Kimia Farma Tbk dan PT. Kereta Api Indonesia pada tahun 2001 dengan meningkatkan daftar persediaan sehingga meningkatnya keuntungan. Akibatnya kepercayaan masyarakat menurun, ditandai dengan menurunnya harga saham secara drastis. Banyak Auditor yang gagal mendeteksi kecurangannya. Sehingga memberikan dampak yang sangat merugikan reputasi dan nama baik Kantor Akuntan Publik.

Berdasarkan latar belakang dan Gap research yang telah dipaparkan di atas, maka peneliti tertarik untuk melakukan penelitian dengan judul "Pengaruh Kepemilikan Institusional, Kepemilikan Manajerial, Ukuran Perusahaan dal Laverage terhadap Integritas Laporan Keuangan". Variabel dependen dalam penelitian yaitu integritas laporan keuangan. Variabel independen dalam penelitian ini yaitu kepemilikan institusional, kepemilikan manajerial, ukuran perusahaan dan laverage. Sampel penelitian ini menggunakan perusahaan pertambangan yang terdaftar di Bursa Efek Indonesia tahun 2013-2018. 
Widya Kusuma Wardhani dan Yuli Chomsatu Samrotun, Pengaruh Kepemilikan Institusional, Kepemilikan Manajerial, Ukuran Perusahaan dan Leverage terhadap Integritas Laporan Keuangan

\section{Teori keagenan}

(Jensen \& Meckling, 1976) mendefinisikan teori agensi sebagai hubungan keagenan suatu kontrak, dimana satu orang atau lebih (prinsipal) meminta pihak lainnya (agen) untuk melaksanakan sejumlah pekerjaan atas nama prinsipal, yang melibatkan pendelegasian beberapa wewenang pembuatan keputusan kepada agen.

Menurut (Eisenhardt, 1989), teori agensi menggunakan tiga asumsi sifat manusia yaitu: 1 . Manusia pada umumya mementingkan diri sendiri (self interest); 2. Manusia memiliki daya pikir terbatas mengenai persepsi masa mendatang (bounded rationality); 3. Manusia selalu menghindari risiko (risk averse).

\section{Integritas Laporan Keuangan}

(Hardiningsih, 2010) mendefinisikan integritas laporan keuangan adalah informasi yang terkandung dalam laporan keuangan dengan menampilkan kondisi suatu perusahaan yang sesungguhnya, tanpa ada yang ditutup-tutupi atau disembunyikan. Sehingga memberikan informasi yang berguna bagi investor dan kreditor atau pihak-pihak lain yang berkepentingan untuk membuat keputusan investasi, kredit dan keputusan sejenis.

\section{Kepemilikan Institusional}

Kepemilikan institusional adalah kepemilikan saham perusahaan oleh institusi keuangan seperti perusahaan asuransi, bank, dana pensiun dan investment banking (Verinoca \& Utama, 2005). Adanya kepemilikan institusional di suatu perusahaan akan mendorong peningkatan pengawasan agar lebih optimal terhadap kinerja manajemen, karena kepemilikan saham mewakili sumber kekuasaan (source of power) yang dapat digunakan untuk mendukung atau sebaliknya terhadap keberadaan manajemen.

\section{Kepemilikan Manajerial}

(Jensen \& Meckling, 1976) menyatakan bahwa kepemilikan saham manajerial dapat membantu menyatukan kepentingan antara manajer dan pemegang saham, yang berarti semakin meningkat proporsi kepemilikan saham manajerial maka semakin baik kinerja perusahaan tersebut. Kepemilikan manajerial juga dapat meningkatkan rasa tanggung jawab manajemen yang lebih besar dalam menjalankan amanah untuk memenuhi keinginan dari pemegang saham yang tidak lain adalah dirinya sendiri.

\section{Ukuran Perusahaan}

(Taures 2011 dalam Saksakotama, 2014) mengatakan bahwa ukuran perusahaan adalah nilai yang menunjukkan kemampuan perusahaan dengan tindakan pengambilan keputusan. Banyaknya tuntutan dari stakeholder yang akan diterima oleh perusahaan- perusahaan skala besar untuk laporan keuangan yang memiliki integritas tinggi, diharapkan dapat mengurangi manajemen untuk praktek kecurangan dalam memberikan informasi keuangan. Semakin besar perusahaan, maka semakin tinggi pula tututan terhadap pengungkapan informasi laporan keuangan yang memilliki integritas tinggi.

\section{Leverage}

(Kasmir, 2015) mengatakan bahwa rasio leverage adalah rasio yang digunakan untuk mengukur sejauh mana aset perusahaan dibiayai dengan utang. Penggunaan utang yang terlalu tinggi akan merugikan perusahaan karena perusahaan akan jatuh ke dalam kategori ekstrim leverage yang akan sulit untuk melepaskan beban utang (Fahmi, 2014). Hal ini akan mendorong manajemen untuk mengungkapkan informasi laporan keuangan lebih transparan dibandingkan perusahaan yang memiliki tingkat leverage rendah. Namun risiko yang dihadapi oleh investor akan meningkat sehingga mereka akan menuntut untuk mendapatkan laba atas investasi mereka.

\section{Penelitian Sebelumnya}

Penelitian yang dilakukan oleh (Pradika \& Hoesada, 2018) menunjukkan hasil bahwa kepemilikan institusional berpengaruh terhadap integritas laporan keuangan. Sedangkan penelitian yang dilakukan oleh (Nurdiniah \& Pradika, 2017) dan (Badewin, 2019) menunjukkan hasil bahwa kepemilikan institusional tidak berpengaruh terhadap integritas laporan keuangan.

Penelitian yang dilakukan oleh (Pancawati Hardiningsih, 2010) menunjukkan hasil bahwa kepemilikan manajerial memiliki pengaruh positif dan signifikan terhadap integritas laporan keuangan. Sedangkan penelitian yng dilakukan oleh (Dewanti Oktadella, 2011) menunjukan hasil bahwa kepemilikan manajerial memiliki pengaruh negatif dan tidak signifikan terhadap integritas laporan keuangan.

Penelitian yang dilakukan oleh (Pradika \& Hoesada, 2018) menunjukkan hasil bahwa ukuran perusahaan berpengaruh terhadap integritas laporan keuangan. Sedangkan penelitian yang dilakukan oleh (Monica \& Wenny, 2016) menunjukkan hasil bahwa ukuran perusahaan tidak berpengaruh terhadap integritas laporan keuangan.

Penelitian yang dilakukan oleh (Pradika \& Hoesada, 2018) menunjukkan hasil bahwa leverage berpengaruh terhadap integritas laporan keuangan. Sedangkan penelitian yang dilakukan oleh (Nurdiniah \& Pradika, 2017) diperoleh hasil bahwa leverage tidak berpengaruh terhadap integritas laporan keuangan. 
Widya Kusuma Wardhani dan Yuli Chomsatu Samrotun, Pengaruh Kepemilikan Institusional, Kepemilikan Manajerial, Ukuran Perusahaan dan Leverage terhadap Integritas Laporan Keuangan

Pengaruh Kepemilikan Institusional Terhadap Integritas Laporan Keuangan

Kepemilikan institusional mengindikasikan kemampuannya untuk menjadi pengawas yang efektif untuk manajemen dalam menyajikan laporan keuangan. Informasi pelaporan keuangan harus disajikan dengan mengedepankan bebas dari salah saji material yang dapat menyesatkan pengguna. Sehingga tercapainya laporan keuangan yang berintegritas tinggi. Hal ini sesuai dengan penelitian yang dilakukan oleh (Fajaryani, 2015) yang menunjukkan bahwa kepemilikan institusional berpengaruh terhadap integritas laporan keuangan. Hipotesis pada penelitian ini diusulkan sebagai berikut : $\mathrm{H}_{1}$ : Kepemilikan institusional berpengaruh terhadap integritas laporan keuangan.

\section{Pengaruh Kepemiikan Manajerial Terhadap Integritas Laporan Keuangan}

Dengan tanggung jawab manajemen yang lebih besar dalam mengelola perusahaan, manajemen akan menyajikan infrormasi laporan keuangan secara jujur. Serta menggambarkan realitas ekonomi yang terjadi. Sehingga semakin besar kepemilikan saham oleh manajemen, maka integritas laporan keuangan akan semakin meningkat. Hal ini sesuai dengan penelitian yang dilakukan oleh (Haq, Suzan, \& Musllih, 2017) yang menunjukkan bahwa kepemilikan manajerial berpengaruh terhadap integritas laporan keuangan. Hipotesis pada penelitian ini diusulkan sebagai berikut :

$\mathrm{H}_{2}$ : Kepemilikan manajerial berpengaruh terhadap integritas laporan keuangan.

\section{Pengaruh Ukuran Perusahaan Terhadap Integritas Laporan Keuangan}

Ukuran perusahaan memiliki peranan penting dalam penyajian laporan keuangan dengan integritas tinggi. Semakin besar ukuran perusahaan, maka tuntutan dari stakeholder yang diterima oleh perusahaan untuk laporan keuangan yang memiliki integritas tinggi akan semakin meningkat. Manajemen diharapkan dapat mengurangi praktek kecurangan dalam menyajikan informasi laporan keuangan yang menyesatkan. Hal ini sejalan dengan penelitian yang dilakukan oleh (Fajaryani, 2015), (Saksakotama, 2014) dan (Gayatri \& Suputra, 2013) yang menemukan bahwa ukuran perusahaan berpengaruh terhadap integritas laporan keuangan. Berdasarkan hal terebut, hipotesis dalam penelitian ini adalah:

$\mathrm{H}_{3}$ : Ukuran perusahaan berpengaruh terhadap Integritas Laporan Keuangan.

\section{Pengaruh Leverage Terhadap Integritas Laporan Keuangan}

Penggunaan utang yang terlalu tinggi akan merugikan perusahaan karena perusahaan akan jatuh ke dalam kategori ekstrim leverage (ekstrim utang) dan akan sulit untuk melepaskan beban utang (Fahmi, 2014). Hal ini sejalan dengan penelitian yang dilakukan oleh (Fajaryani, 2015) yang menunjukkan bahwa leverage berpengaruh terhadap integritas laporan keuangan. Berdasarkan hal ini, pengembangan hipotesis dalam penelitian ini :

$\mathrm{H}_{4}$ : Leverage berpengaruh terhadap Integritas Laporan Keuangan.

\section{METODE}

Penelitian ini bersifat kuantitatif. Pengujian hipotesis dalam penelitian ini menggunakan model regresi linier berganda.

\section{Populasi dan Sampel Penelitian}

Populasi yang digunakan dalam penelitian ini adalah seluruh perusahaan pertambangan yang terdaftar di Bursa Efek Indonesia (BEI) periode 2013-2018. Sampel dalam penelitian ini dipilih dengan metode purposive sampling, dengan kriteria sebagai berikut :

1. Perusahaan pertambangan yang terdaftar di Bursa Efek Indonesia (BEI) pada periode 2013-2018.

2. Perusahaan pertambangan yang mempublikasikan laporan tahunannya secara berturut-turut periode 2013-2018.

3. Perusahaan pertambangan yang menggunakan satuan mata uang Rupiah (Rp) periode 2013-2018.

4. Perusahaan pertambangan yang mengalami laba secara berturut-turun periode 2013-2018.

5. Perusahaan mengungkapkan data yang diperlukan dalam penelitian secara lengkap selama periode 2013-2018.

Jumlah sampel yang dignakan dalam penelitian ini adalah sebanyak 54 sampel perusahaan pertambangan yang terdaftar di Bursa Efek Indonesia periode 20132018.

\section{Variabel}

Variabel independen yang digunakan dalam penelitian ini adalah kepemilikan institusional, kepemilikan manajerial, ukuran perusahaan dan leverage. Variabel dependen dalam penelitian ini adalah Integritas Laporan Keuangan.

\section{Metode Analisis}

Perhitungan integritas laporan keuangan.

Dalam penelitian ini integritas laporan keuangan diukur dengan menggunakan indeks konservatisme.

$\mathrm{ILK}_{\text {it }}=$ Harga Pasar Saham

Nilai Buku Saham

Keterangan :

ILK $_{\text {it }}$ : Integritas Laporan Keuangan Perusahaan i pada tahun $\mathrm{t}$

\section{Pengukuran Kepemilikan Institusional}

Kepemilikan institusional merupakan jumlah saham yang dimiliki pihak eksternal, seperti bank, 
Widya Kusuma Wardhani dan Yuli Chomsatu Samrotun, Pengaruh Kepemilikan Institusional, Kepemilikan Manajerial, Ukuran Perusahaan dan Leverage terhadap Integritas Laporan Keuangan

perusahaan asuransi, maupun institusi lainnya. Variabel ini dapat diukur dengan menggunakan skala rasio dari presentase jumlah saham yang dimiliki oleh perusahaan dibagi jumlah saham yang beredar. Rumus kepemilikan institusional yaitu :

$\mathrm{INST}=\mathrm{Jml}$ saham yg dimiliki perusahaan $\mathrm{X} \quad 100 \%$

$$
\text { Jumlah saham beredar }
$$

\section{Pengukuran Kepemilikan Manajerial}

Kepemilikan manajerial dapat diukur menggunakan rasio managerial ownership, yaitu pengukuran yang dilakukan dengan presentase jumlah saham yang dimiliki oleh manajemen perusahaan seperti dewan direksi dan dewan komisaris kemudian dibagi dengan jumlah saham yang beredar. Rumus kepemilikan manajerial yaitu :

MOWN = Jml saham yg dimiliki manaj. X 100\% Jumlah saham beredar

\section{Ukuran Perusahaan}

Ukuran perusahaan merupakan faktor untuk mengklasifikasikan suatu entitas ke dalam perusahaan besar, menengah, atau kecil (Asri \& Suardana, 2016). Ukuran perusahaan dalam penelitian ini dapat dihitung dengan logaritma natural (Ln) dari total aset. Ukuran perusahaan dapat diukur dengan menggunakan rumus menurut (Oktamawati, 2017) sebagai berikut :

Size $=$ LN $($ Total Aset $)$

\section{Pengukuran Leverage}

Leverage adalah rasio yang digunakan untuk mengukur sejauh mana aktiva perusahaan dibiayai dengan hutang (Kasmir, 2012). Rasio yang digunakan adalah Debt to Equity Ratio (DER). DER merupakan rasio keuangan yang menggambarkan kemampuan perusahaan untuk membayar kembali hutang yang dengan menggunakan modal yang dapat diukur dengan menggunakan rumus menurut (Oktamawati, 2017) sebagai berikut :

$$
\text { DER }=\frac{\text { Total Hutang }}{\text { Total Modal }}
$$

\section{HASIL DAN PEMBAHASAN}

Penelitian ini bertujan untuk menguji dan menganalisis kepemilikan institusional, kepemilikan manajerial, ukuran perusahaan dan laverage terhadap integritas laporan keuangan. Penelitian ini bersifat kuantitatif. Pengujian hipotesis menggunakan model regresi linier berganda. Populasi dalam penelitian ini adalah seluruh perusahaan pertambangan yang terdaftar di BEI periode 2013-2018. Sampel dipilih dengan menggunakan purposive sampling yaitu dengan kriteriakriteria yang telah ditentukan. Jumlah sampel yang dignakan dalam penelitian ini adalah sebanyak 54 sampel perusahaan pertambangan yang terdaftar di Bursa Efek Indonesia periode 2013-2018. Instrumen Penelitian berupa dokumentasi Laporan Tahunan perusahaan pertambangan yang terdaftar di BEI periode 2013-2018 yang didokumentasikan melalui situs web www.idx.co.id.

\section{Statistik Deskriptif dan Hasil Pengujian Asumsi Klasik}

Tabel 1. Hasil Uji Deskriptif

\begin{tabular}{lccrrr}
\hline Variabel & N & Min & \multicolumn{1}{c}{ Max } & \multicolumn{1}{c}{ Mean } & \multicolumn{1}{c}{ Std. Dev } \\
\hline KI & 54 & 0 & 902 & 436,07 & 309,783 \\
KM & 54 & 0 & 762 & 61,31 & 153,888 \\
UP & 54 & 2691 & 30716 & 25913,31 & 6794,780 \\
Leverage & 54 & 3 & 846 & 421,93 & 211,674 \\
ILK & 54 & 107 & 8209 & 1433,43 & 1587,573 \\
\hline
\end{tabular}

Sumber : Olah Data SPSS, 2019

Berdasarkan kriteria pengambilan sampel sesuai, maka diperoleh sampel sebanyak 54 perusahaan pertambangan yang terdaftar di Bursa Efek Indonesia periode 2013-2018. Berdasarkan uji statistik deskriptif pada Tabel 1 dapat dilihat bahwa Kepemilikan Institusional memiliki nilai minimum sebesar 0 , nilai maksimum sebesar 902, dengan rata-rata sebesar 436,07 dan standar deviasi dari kepemilikan institusional sebesar 309,783. Kepemilikan Manajerial memiliki nilai minimum sebesar 0, nilai maksimum sebesar 762, dengan nilai rata-rata sebesar 61,31 dan standar deviasi sebesar 153,888. Ukuran Perusahaan memiliki nilai minimum sebesar 2691, nilai maksimum sebesar 30716, dengan nilai rata-rata sebesar 25913,31 dan standar deviasi sebesar 6794,780. Leverage memiliki nilai minimum sebesar 3, nilai maksimum sebesar 846, dengan nilai rata-rata sebesar 421,93 dan standar deviasi sebesar 211,674. Integritas Laporan Keuangan memiliki nilai minimum sebesar 107, nilai maksimum sebesar 8209, dengan nilai rata-rata sebesar 1433,43 dan standar deviasi sebesar 1587,573.

Uji asumsi klasik dilakukan agar uji regresi linear berganda dalam penelitian ini memiliki hasil yang signifikan dan representatif. Berdasarkan hasil uji asumsi klasik yang telah dilakukan menunjukkan bahwa semua model regresi dalam penelitian ini memenuhi asumsi klasik.

Tabel 2. Hasil Uji Regresi Linear Berganda

\begin{tabular}{llcccl}
\hline Hipotesis & $\mathrm{T}_{\text {hitung }}$ & $\mathrm{T}_{\text {tabel }}$ & Sig. & Std. & Ket. \\
\hline H1 & 2,218 & $>2,010$ & 0,031 & 0,05 & Diterima \\
H2 & 0,137 & $>2,010$ & 0,892 & 0,05 & Ditolak \\
H3 & $-1,275$ & $>2,010$ & 0,208 & 0,05 & Ditolak \\
H4 & $-1,475$ & $>2,010$ & 0,147 & 0,05 & Ditolak \\
\hline
\end{tabular}

Sumber : Olah Data SPSS, 2019 
Widya Kusuma Wardhani dan Yuli Chomsatu Samrotun, Pengaruh Kepemilikan Institusional, Kepemilikan Manajerial, Ukuran Perusahaan dan Leverage terhadap Integritas Laporan Keuangan

\section{Hasil Pengujian Hipotesis}

Pengaruh Kepemilikan Institusional Terhadap Integritas Laporan Keuangan

Berdasarkan hasil perhitungan Tabel 2 kepemilikan institusional memiliki nilai $\mathrm{T}_{\text {hitung }}$ sebesar 2,218 dengan nilai signifikan sebesar 0,031 . Nilai $T_{\text {hitung }}$ tersebut lebih besar dari $\mathrm{T}_{\text {tabel }}$ dan nilai signifikan lebih besar dari 0,05 . Hal ini berarti kepemilikan institusional memiliki pengaruh terhadap integritas laporan keuangan. Maka dapat disimpulkan bahwa hipotesis 1 diterima.

\section{Pengaruh Kepemilikan Manajerial Terhadap Integritas Laporan Keuangan}

Berdasarkan hasil perhitungan Tabel 2 kepemilikan manajerial memiliki nilai $\mathrm{T}_{\text {hitung }}$ sebesar 0,137 dengan nilai signifikan sebesar 0,892 . Nilai $T_{\text {hitung }}$ tersebut lebih kecil dari $\mathrm{T}_{\text {tabel }}$ dan nilai signifikan lebih besar dari 0,05. Hal ini berarti kepemilikan manajerial tidak memiiki pengaruh terhadap integritas laporan keuangan. Maka dapat disimpulkan bahwa hipotesis 2 ditolak.

\section{Pengaruh Ukuran Perusahaan Terhadap Integritas Laporan Keuangan}

Berdasarkan hasil perhitungan Tabel 2 ukuran perusahaan memiliki nilai $T_{\text {hitung }}$ sebesar $-1,275$ dengan nilai signifikan sebesar 0,208 . Nilai $T_{\text {hitung }}$ tersebut lebih kecil dari $T_{\text {tabel }}$ dan nilai signifikan lebih besar dari 0,05 . Hal ini berarti ukuran perusahaan tidak memiliki pengaruh terhadap integritas laporan keuangan. Maka dapat disimpulkan bahwa hipotesis 3 ditolak.

\section{Pengaruh Leverage Terhadap Integritas Laporan Keuangan}

Berdasarkan hasil perhitungan Tabel 2 leverage memiliki nilai $\mathrm{T}_{\text {hitung }}$ sebesar $-1,475$ dengan nilai signifikan sebesar 0,147 . Nilai $\mathrm{T}_{\text {hitung }}$ tersebut lebih kecil dari $\mathrm{T}_{\text {tabel }}$ dan nilai signifikan lebih besar dari 0,05. Hal ini berarti leverage tidak memiliki pengaruh terhadap integritas laporan keuangan. Maka dapat disimpulkan bahwa hipotesis 4 ditolak.

Tabel 3. Hasil Uji Koefisien Determinan

\begin{tabular}{ccl}
\hline Model & Adjusted $R$ Square & \multicolumn{2}{c}{ Keterangan } \\
\hline 1 & 0.129 & Kepemilikan institusional, \\
& kepemilikan manajerial, & ukuran perusahaan dan \\
& leverage secara simultan \\
& berpengaruh & terhadap \\
& integritas laporan keuangan \\
& sebesar 19,5\%. \\
&
\end{tabular}

Sumber : Olah Data SPSS, 2019

Berdasarkan hasil uji $\mathrm{F}$ yang telah dilakukan menyatakan bahwa model regresi yang digunakan dalam penelitian ini layak. Berdasarkan hasil uji koefisien determinasi $\left(\mathrm{R}^{2}\right)$ pada Tabel 3 menunjukkan bahwa nilai
Adjusted $R$ square sebesar 0,129. Hal tersebut berarti bahwa prosentase sumbangan pengaruh kepemilikan institusional, kepemilikan manajerial, ukuran perusahaan dan leverage berpengaruh terhadap integritas laporan keuangan sebesar $19,5 \%$. Sedangkan sisanya yaitu $80,5 \%$ dipengaruhi oleh variabel lain diluar variabel kepemilikan institusional, kepemilikan manajerial, ukuran perusahaan dan leverage.

\section{Pembahasan}

Berdasarkan pengujian yang telah dilakukan dengan beberapa hipotesis, Penelitian ini menguji pengaruh kepemilikan institusional, kepemilikan manajerial, ukuran perusahaan dan leverage terhadap integritas laporan keuangan. Berikut ini adalah hasil dari pengujian yang telah dilakukan dalam penelitian ini, dapat dikemukakan sebagai berikut :

\section{Pengaruh Kepemilikan Institusional terhadap Integritas Laporan Keuangan}

Berdasarkan hasil pengujian hipotesis (uji t) yang dilakukan menunjukkan bahwa kepemilikan institusional berpengaruh terhadap integritas laporan keuangan. Penelitian ini sejalan dengan penelitian yang dilakukan oleh (Pradika \& Hoesada, 2018) yang menyatakan bahwa kepemilikan institusional berpengaruh terhadap integritas laporan keuangan. Tetapi berbanding terbalik dengan penelitian yang dilakukan oleh (Nurdiniah \& Pradika, 2017) dan (Badewin, 2019) yang menyatakan bahwa kepemilikan institusional tidak berpengaruh terhadap integritas laporan keuangan.

Perusahaan dapat memanfaatkan kepemilikan saham perusahaannya oleh institusi keuangan seperti perusahaan asuransi, bank, dana pensiun, investment bankin dan lain-lain dimana dapat meningkatkan menyajian laporan keuangan yang berintegritas. Perusahaan yang jumlah sahamnya dimiliki pihak eksternal semakin kecil akan meningkatkan penyajian laporan keuangannya yang berintegritas tinggi.

\section{Pengaruh Kepemilikan Manajerial terhadap Integritas Laporan Keuangan}

Berdasarkan hasil pengujian hipotesis (uji t) yang dilakukan menunjukkan bahwa kepemilikan manajerial tidak berpengaruh terhadap integritas laporan keuangan. Penelitian ini sejalan dengan penelitian yang dilakukan oleh Laila Arvida (2013) yang menyatakan bahwa kepemilikan manajerial tidak berpengaruh terhadap integritas laporan keuangan. Tetapi berbanding terbalik dengan penelitian yang dilakukan oleh Herawati (2007) yang menyatakan bahwa kepemilikan manajerial berpengaruh terhadap integritas laporan keuangan.

Perusahaan yang semakin kecil proporsi kepemilikan manajerialnya, maka manajemen cenderung tidak terlalu mementingkan kepentingan pemegang saham termasuk dirinya sendiri karena akan 
Widya Kusuma Wardhani dan Yuli Chomsatu Samrotun, Pengaruh Kepemilikan Institusional, Kepemilikan Manajerial, Ukuran Perusahaan dan Leverage terhadap Integritas Laporan Keuangan

menimbulkan integritas laporan keungan yang kecil pula. Rendahnya kepemilikan saham manajerial akan membuat integritas laporan keuangan menjadi rendah. Sehingga manajemen bertindak mengutamakan kepentingan pribadinya. Maka menimbulkan permasalahan keagenan/ konflik agensi diantara kedua belah pihak.

\section{Pengaruh Ukuran Perusahaan terhadap Integritas Laporan Keuangan}

Berdasarkan hasil pengujian hipotesis (uji t) yang dilakukan menunjukkan bahwa ukuran perusahaan tidak berpengaruh terhadap integritas laporan keuangan. Penelitian ini sejalan dengan penelitian (Pradika \& Hoesada, 2018) yang menyatakan bahwa ukuran perusahaan tidak berpengaruh terhadap integritas laporan keuangan. Tetapi berbanding terbalik dengan penelitian yang dilakukan oleh (Nurdiniah \& Pradika, 2017) yang menyatakan bahwa ukuran perusahaan berpengaruh terhadap integritas laporan keuangan.

Aset perusahaan bukanlah menjadi pertimbangan satu-satunya bagi para investor untuk menanamkan modalnya. Aset yang dimiliki perusahaan belum digunakan secara maksimal oleh manajer maka dari itu tingkat integritas laporan keuangan belum maksimal. Dengan demikian perusahaan yang memiliki aset banyak sekalipun perlu memanfaatkan semaksimal mungkin sehingga integritas lapporan keuangan dapat ditingkatkan maka para investor akan tertarik dan berinvestasi.

\section{Pengaruh Leverage terhadap Integritas Laporan Keuangan}

Berdasarkan hasil pengujian hipotesis (uji t) yang dilakukan menunjukkan bahwa leverage tidak berpengaruh terhadap integritas laporan keuangan. Penelitian ini sejalan dengan penelitian yang dilakukan oleh (Nurdiniah \& Pradika, 2017) yang menyatakan bahwa leverage tidak berpengaruh terhadap integritas laporan keuangan. Berbanding terbalik dengan penelitian yang dilakukan oleh (Pradika \& Hoesada, 2018) yang menyatakan bahwa leverage berpengaruh terhadap integritas laporan keuangan.

Leverage yang tinggi pada perusahaan menunjukkan tingkat hutang yang tinggi daripada modal sendiri (equity). Tingginya tingkat hutang dalam suatu perusahaan akan menimbulkan persepsi investor yang akan menanamkan modalnya. Sehingga akan memicu manajemen perusahaan untuk melakukan window dressing terhadap laporan keuangan. Para investor akan menimbang-nimbang jika perusahaan memiliki hutang yang tinggi, karena akan berdampak pada kerugian yang akan terjadi di masa mendatang.

\section{SIMPULAN}

Berdasarkan bukti empiris diperoleh hasil bahwa kepemilikan institusional berpengaruh terhadap integritas laporan keuangan. Sedangkan kepemilikan manajerial, ukuran perusahaan dan leverage tidak berpengaruh terhadap integritas laporan keuangan. Populasi dalam penelitian ini hanya perusahaan pada sektor pertambangan, diharapkan penelitian selanjutnya dapat menambah sektor atau mengganti sektor penelitian. Faktor-faktor yang mempengaruhi integritas laporan keuangan sangat banyak, sedangkan dalam penelitian ini hanya menggunakan 4 variabel independen saja yang ternyata masih kurang dapat menjelaskan variabel dependennya. Hal ini dapat dilihat dari nilai koefisien determinasi Adjusted $R^{2}$ hanya $19,5 \%$ yang berarti bahwa masih terdapat $80,5 \%$ variabel lain yang mempengaruhi integritas laporan keuangan. Diharapkan penelitian selanjutnya dapat menggunakan variabel independen lain yang mempengaruhi integritas laporan keuangan.

\section{DAFTAR PUSTAKA}

Badewin. (2019, Januari-Juni). Pengaruh Kepemilikan Institusional, Komite Audit dan Kualitas Audit Terhadap Integritas Laporan Keuangan pada Perusahaan Manufaktur yang Terdaftar di BEI. Jurnal Akuntansi dan Keuangan, 8, No. 1, 19-31.

Eisenhardt, K. M. (1989). An Assesment and Review. Academy of Management Review, 14 (1), 57-74.

Fahmi, I. (2014). Analisis Laporan Keuangan.

Fajaryani, A. (2015). Analisis Faktor-Faktor yang mempengaruhi Integritas Laporan Keuangan (Studi Empiris pada Perusahaan Pertambangan yang Terdaftar di Bursa Efek Indonesia Periode 2008-2013). Jurnal Nominal, 4 (1), 67-82.

Gayatri, I., \& Suputra, I. (2013). engaruh corporate governance, ukuran perusahaan dan leverage terhadap integritas laporan keuangan. E-Jurnal Akuntansi Universitas Udayana, 5(2), 345-360.

Haq, F., Suzan, L., \& Musllih, M. (2017). Pengaruh Kepemilikan Manajerial dan Financial Distress Terhadap Integritas Laporan Keuangan. 7, No 1.

Hardiningsih. (2010). Pengaruh Independensi, Corporate Governance, dan Kualitas Audit Terhadap Integritas Laporan Keuangan.

Jensen, M., \& Meckling, W. (1976). Theory of the Firm : Managerial Behaviour, Agency Cost, and Ownership Structure. Journal of Financial Economics, 3 (4), 305-360.

Kasmir. (2012). Analisis Laporan Keuangan. Jakarta: PT RajaGrafindo Persada.

Kasmir. (2014). Analisis Laporan Keuangan (Cetakan Ketujuh ed.). Jakarta: Rajawali Pers.

Kasmir. (2015). Analisis Laporan Keuangan.

Kim, J. H., \& Im, C. C. (2017). The Study On The Effect And Determinants Of Small- And Medium- Sized 
Widya Kusuma Wardhani dan Yuli Chomsatu Samrotun, Pengaruh Kepemilikan Institusional, Kepemilikan Manajerial, Ukuran Perusahaan dan Leverage terhadap Integritas Laporan Keuangan

Entities Conducting Tax avoidance. The Journal Of Applied Business Research - March/April 2017, Volume 33, Number 2.

Mulyadi. (2011). Auditing. Jakarta: Salemba Empat.

Mulyani, S., Wijayanti, A., \& Masitoh, E. (2018). Pengaruh Corporate Governance Terhadap Tax Avoidance. Jurnal Riset Akuntansi dan Bisnis Airlangga Vol.3 No.1 2018, ISSN: 2548-4346.

Nurdiniah, D., \& Pradika, E. (2017). Effect of Good Corporate Governance, KAP Reputation, Its Size and Leverage on Integrity of Financial Statements. International Journal of Economics and Financial Issues, 7 (4), 174-181.

Pradika, E., \& Hoesada, J. (2018, October 10). Integrity of Financial Statement: Big is Not Guarantee.

Saksakotama, P. (2014). Determinan Integritas Laporan Keuangan Perusahaan Manufakur di Indonesia. Journal of Accounting, 3(2), 1-13.

Taures 2011 dalam Saksakotama, P. (2014). Determinan Integritas Laporan Keuangan Perusahaan Manufaktur di Indonesia. Journal of Accounting, 3 (2), 1-13.

Verinoca, S., \& Utama, S. (2005, September 15-16). Simposium Nasional Akuntansi XVI. 